\title{
A Different Mode of Exchange: The Mamurrng Ceremony of Western Arnhem Land
}

\author{
Reuben Brown
}

\section{A sensory overload}

'Hold on!' I shout to my partner Rachel and yabok (K: sister) ${ }^{1}$ Rhonda, as we hit a wave that almost sends us flying over the side of our tin boat. We grip the edge of the boat tightly, and I check to see whether the recording gear at my feet is still dry. We are now completely at the whim of the ocean as our boat skips along the waves, tracking from Sandy Creek, on the mainland of Arnhem Land in the north coast of Australia, to Warruwi, Goulburn Island-where the Mamurrng (diplomacy or exchange ceremony; see Berndt 1951: 156) will take place. Back in the Aboriginal community of Gunbalanya, where my adopted family reside and where we began our journey, the surrounding rocks of the Arnhem Land plateau are baking and the wetlands drying out to a crust, as the hot weather of the dry season continues to scorch the earth, with no rain in sight. But out here, the wind and spray of the ocean provides welcome

1 Throughout this article, significant words relating to western Arnhem Land songs in the Aboriginal languages of Kunwinjku $(\mathrm{K})$ and Mawng $(\mathrm{M})$ are indicated in italics (except for proper nouns such as the names of people and song-sets). English translations are glossed in brackets the first time the word appears in the text. I adopt standard orthographies for both Kunwinjku and Mawng. 
relief from the harsh build-up of heat. In the distance we can now see Fletcher Point - the southern tip of Goulburn Island (see Figure 1). As we slow down and cruise in toward the island, the boat steadies once more, and I glimpse the familiar sight of a flat, horizontal, elevated shoreline with savannah woodland. Trees are perched right on the edge of the cliff, which drops down steeply to the beach, suddenly exposing the layers of topsoil and clay, which contrast starkly against the bright turquoise colour of the shallow Arafura Sea; it looks almost as though someone had taken a giant spade and dug out the crust of earth above the sea level (see Figure 2).

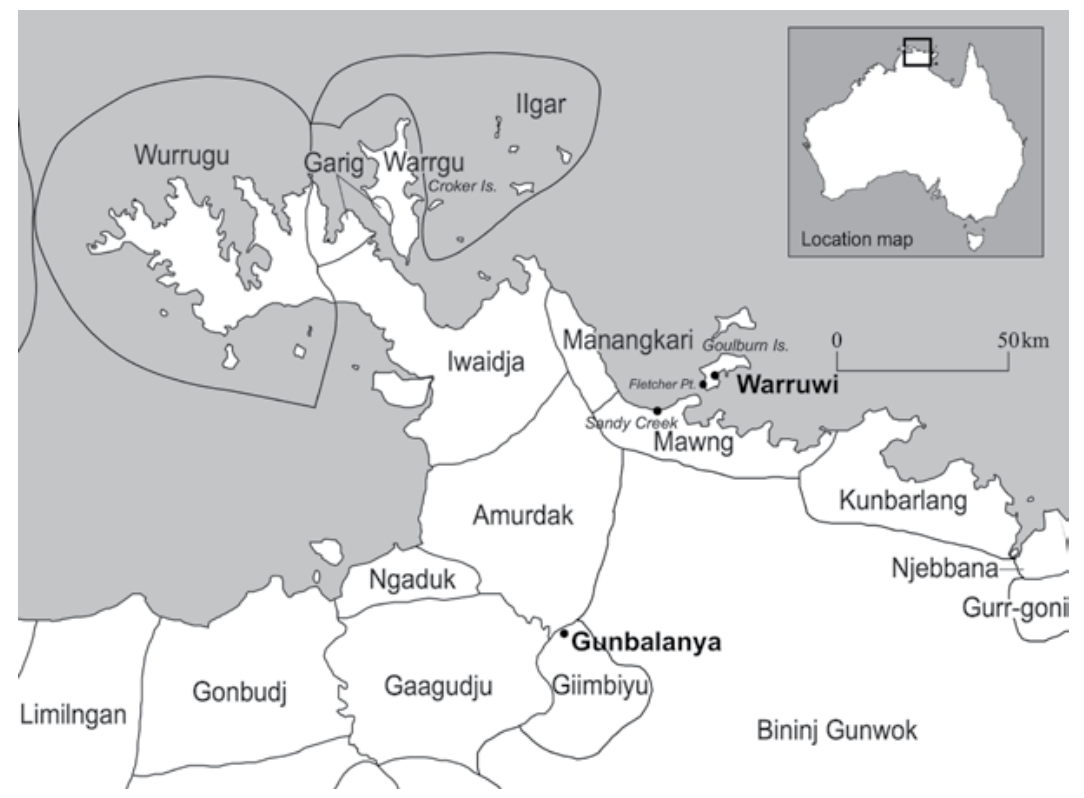

Figure 1. Aboriginal communities of Warruwi and Gunbalanya, western Arnhem Land, showing pre-contact land and language affiliations

Source: Courtesy of Aidan Wilson, used with permission

After we have arrived and settled in at Warruwi, I sit near the skeletal wooden frame of an old mission-era church and close my eyes momentarily, allowing that strong sea breeze to pass over me, ventilating my clothing and cooling my hair and face. Our hosts Jenny and David Manmurulu come over to greet the visiting group. They have been preparing for the ceremony, and have with them several balls of brightly coloured lambswool that Linda Barwick and Allan Marett had sent them. They take a thread of blue yarn and measure my waist, torso, and head with it. Then Jenny takes the length and loops it into many strands, forming a design that 
sits over my shoulders, joined at the back and crossed over at the front. David has made a headband for me with another colour, which fits snugly. He explains that I will be wearing these pieces the following day when they 'give [me] Mamurrng', but I can't have them now.

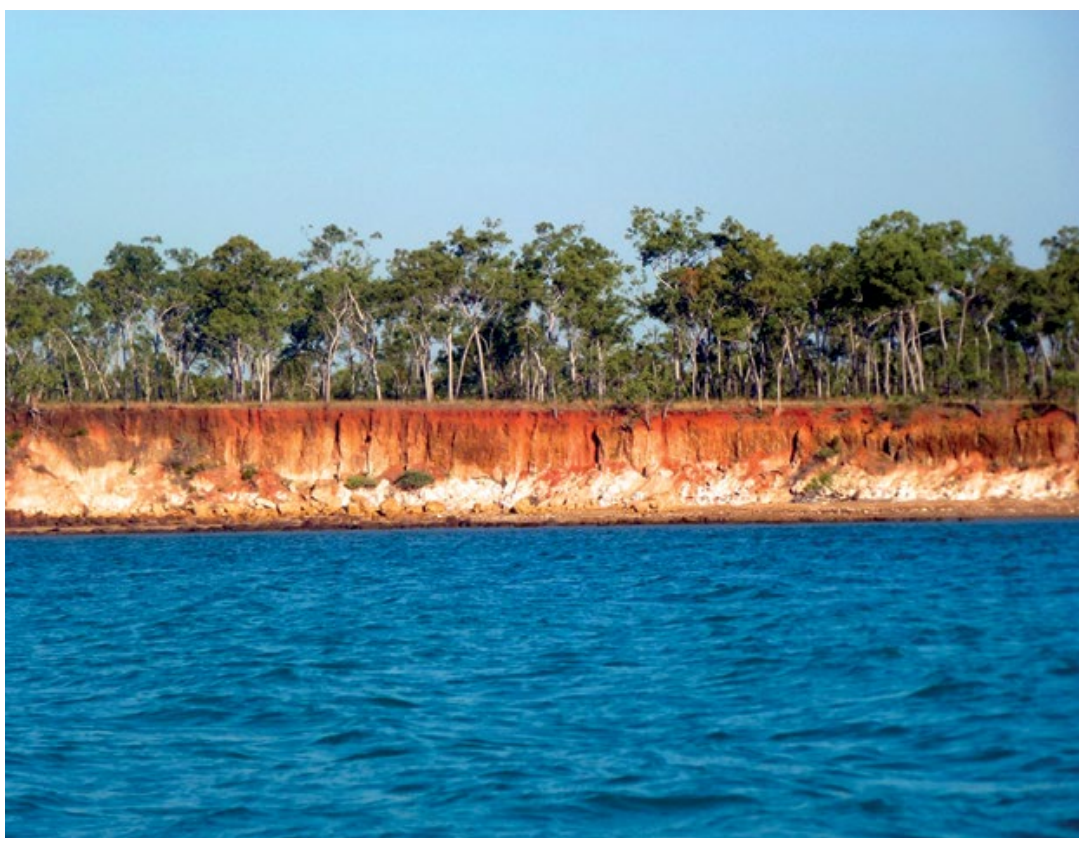

Figure 2. Savannah woodlands, topsoil and delek (K: white ochre) on the shoreline at Fletcher Point, south Goulburn Island

That evening as the sun is going down, we are invited to come and listen to the Inyjalarrku ensemble give a performance as a 'warm-up' for the main event the next day. We meet at the ceremony ground that has been pre-prepared with sand, and David Manmurulu invites me to sit with him and his sons on a tarpaulin rolled out for the singers and didjeridu player. I am struck by the incredible power and unity of their singing, the complexity of the clapstick beating, and the tempo changes in the music. I clap along to the beat, but find myself frequently caught out as it slows down or speeds up midway through a verse. As the clapstick beat gets faster, the dancers respond by rising to their feet and dancing, taking a shirt or a pair of thongs $s^{2}$ in their hands and converting them into dance props. They have a bucket of delek (K: white ochre) on hand that they

2 Light sandals or 'flip-flops'. 
dip into, slapping the clay over their arms and legs. The synchronicity of their movement tells me that they know these songs intimately. The fast clapstick beat seems to have transformed their mood to one of exhilaration; they crack jokes with one another, laugh, and call others over to join in the dance. Sitting amongst the ensemble, a warm sensation comes over me as I feel the vibrations of the arrawirr (M: didjeridu) in my stomach, while at the same time I am energised by the higher frequency sounds of the singing and the sharp sound of the nganangka (M: clapstick) beat that almost pierces my ears.

The following afternoon we receive the word that the Mamurrng will begin soon, and start to gather once more. The families of the dancers arrive with their kids, and position themselves away from the ceremony ground as they ready themselves for the performance. The women wrap blue cloth around their waists to create a skirt. They mix ochre and water, rubbing the white paste into one another's skin in a pattern of rings across the arms and legs, and a diagonal stripe across the chest. The men gather in another area with more cloth, ripping it up and converting it into skirts and naga. ${ }^{3}$ They slap the delek over their skin with ironbark branches. Jenny Manmurulu brings me over to where the women are preparing, and I take my shirt off so that she can put the Mamurrng outfit around my shoulders. My karrang (K: mother), who is the kin mother of my adopted sisters who have accompanied me from Gunbalanya, makes two more woollen armlets for me to wear, and fastens them above my elbows. My partner also has a headband of the same colour to wear, while the rest of my Bininj (K: Aboriginal) family wear different coloured headbands too: we are like colour-coded Mamurrng recipients. Jenny sends me over to the men for further preparations. The arrarrkpi (M: male $)^{4}$ dancers take me to a more secluded spot and help me to put on my own naga. Feeling somewhat exposed and just a little self-conscious, the next stage-under Jenny's instruction - is for me to cover my body in red ochre (Figure 3). I enjoy the ochre on my skin: it feels cool and calming, like a protective layer. It's a simple act, this rubbing of earth into the body, and yet profoundly symbolic and affecting. Holding layers of the country on our skin, ${ }^{5}$ we are all just about ready to start, and I go over and sit with the rest of the recipient party to wait for the Mamurrng.

3 Loincloth worn by arrarrkpi (M: males) for ceremonial dance.

4 Arrarrkpi also means 'person' or 'Aboriginal person' in Mawng language.

5 Here I use the term 'country' acknowledging the Indigenous Australian sense of the word, as a 'living entity' that is sentient, and can hear, smell, and take notice of the people that inhabit it (Rose 1996: 7). 


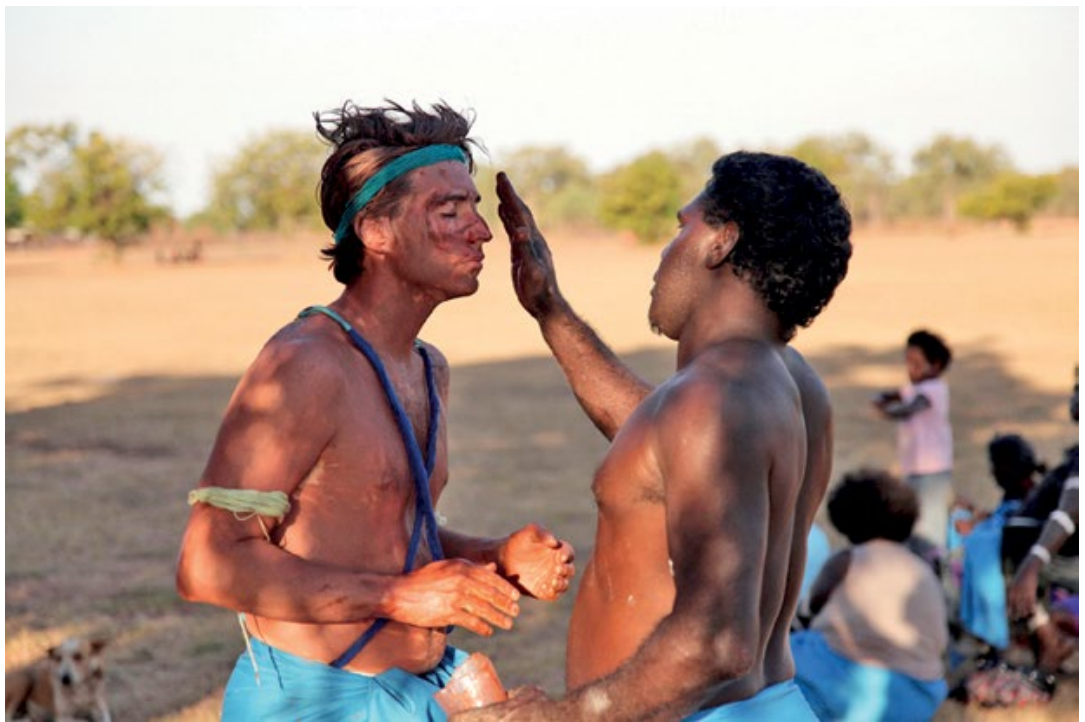

Figure 3. Roderick Lee helps to cover the author in red ochre in preparation for the Mamurrng

Source: Martin Thomas, used with permission

It's late in the evening now and the sun has gone down. We have just witnessed an hour or so of spectacular dancing and singing, led by the 'old man' Charlie Mangulda-haunting melodies from the Amurdak ancestors of the mainland (see Figure 1). The mamurrng pole has been laid at my feet and taken back again, and now the Inyjalarrku group is singing once more. Sitting next to me this whole time, my second yabok Donna is a reassuring presence, clapping along and enjoying the music with her young daughters, who film the ceremony on their mobile phones. Jenny Manmurulu and the other warramumpik (M: women) keep a steady hold on the beat of the clapsticks. They sway their torsos and arms in sync with the rhythm that seems to have taken hold of them-lifting a hand subtly to their heads and pausing with it there as the clapsticks skip a beat, before resuming their swaying once again as the beat continues.

Suddenly, a ghostly figure covered head to toe in delek emerges from behind the singing ensemble through the dancers in front, and strides his way over to me, swaying his loping arms and cocking his head from side to side, stepping with the beat of the clapsticks. There is a sense of gravity to his movement and he has a somewhat anguished expression. He fixes his sad eyes on me, then away to the distance, then back at me. It is almost as though he is looking through me. Taking the mamurrng between his 
teeth, with each beat of clapsticks, he stretches his arms out towards me and brings them back into his chest, as though he were drawing me in, and pushing me away. He holds one arm out to us and rotates his hand (see Figure 4). Is this a refusal? A wave goodbye? The clapstick beating gets louder as the ensemble edges closer to us, and the dancers continue their shouts of 'agh!' and 'yi!' over the top of the music. My skin is tingling. The warramumpik form a line, now standing over us, and we are hit with a wall of beautiful solid sound and flicks of sand from moving feet, as the Inyjalarrku singers move into the final nigi (M: mother) song. ${ }^{6}$ As the song comes to a climax, the ghostly figure reaches down and releases the mamurrng at my feet, just as the last solitary clapstick beat rings out. He moves back into line with the dancers and they all hold one arm out, showing me the palms of their hands. 'Oh:::: ... oh-ohoh-oh, oh-oh-oh-oh' they sing. They are saying bobo (K/M: goodbye). Responding to their own farewell, but in a quieter tone now, the dancers and the audience let out a collective cry of appreciation. The performers come over to us and, one by one, offer a shake of hands.

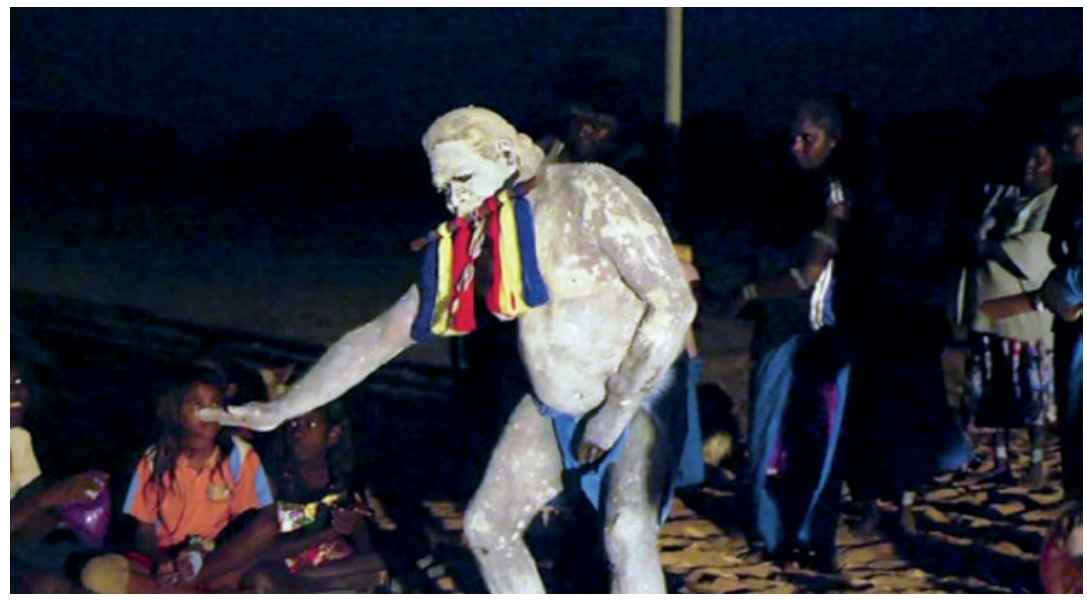

Figure 4. David Manmurulu performs the final handover of the mamurrng, dancing as the yumparrparr, a mythical giant spirit, as children from Warruwi and Gunbalanya look on

Source: Still from film by Gus Berger

6 The nigi or 'mother' song is performed at the end of a particular stage of the ceremony. It is marked by the fact that it has the slowest tempo; all the other songs are considered its 'children'. 
This article examines a ritual diplomacy ceremony performed in western Arnhem Land called the Mamurrng, and the particular modes of exchange that are enacted through the performance of manyardi, a public ceremonial dance-song genre of western Arnhem Land. ${ }^{7}$ I consider both social and musical factors in addressing the question: what is actually exchanged in such a ceremony?

Underpinning the songs and dances of manyardi and other public Aboriginal song traditions from the Top End of Australia are complex patterns of clapstick beating in different tempi, combined with didjeridu accompaniment, described in the literature as 'rhythmic modes' (Barwick 2002; Marett 2005: 203-210; Marett, Barwick, and Ford 2013: 58-59). In ceremonial contexts that involve multiple language groups from around the region coming together, it has been suggested that rhythmic modes help to distinguish the 'aural identity' of the various groups and their song repertories (Anderson 1995; Toner 2001: 82-100; Barwick 2002; Marett, Barwick, and Ford 2013: 47). Expanding on the thesis that Indigenous Australian societies consciously foster variegation in music as well as language (Evans 2010: 14; Barwick 2011: 348; Treloyn 2014), I examine how particular rhythmic modes both differentiated and unified the repertories, or 'song-sets' (as they are referred to in the literature on western Arnhem Land song), ${ }^{8}$ that were performed as part of a Mamurrng ceremony at Warruwi in 2012.

The Mamurrng ceremony is initiated when a lock of hair is taken from the future recipient(s) and woven by the givers of the ceremony with beeswax into a wooden pole (the mamurrng) decorated with brightly coloured tassels of wool. This mamurrng pole later becomes the centrepiece of a ceremonial dance lasting several nights. It is passed on to numerous dancers through the performance of manyardi until it is eventually handed over to the recipient(s) in an emotional exchange. As scholars have noted, through this ceremony, the mamurrng pole becomes imbued with social and spiritual meanings, and ineffable aspects of both the giver's and the recipient's identities (Berndt 1951: 174; Weiner 1992: 6; Corn 2002: 87; Garde 2006: 62). The lock of hair embedded in the mamurrng represents the identity of recipients, while the performance of ancestral songs

7 Also known as kun-borrk in Bininj Gunwok language. For further discussion of western Arnhem Land song, see Barwick, Birch, and Evans (2007); Barwick, O'Keeffe, and Singer (2013: 46-47); Brown (2014); Garde (2006); and O’Keeffe (2010).

8 See Garde (2006); Barwick, Birch, and Evans (2007); and O’Keeffe (2007). 
and dances represents givers' ancestral knowledges and relationships to traditional country. ${ }^{9}$ In this sense, the mamurrng becomes what Annette Weiner refers to as an 'inalienable gift'; unlike other commodities that become private property once they are exchanged, the mamurrng remains attached to the donor, creating a bond between donor and recipient (Weiner, cited in Keen 2004: 352).

Diplomacy ceremonies such as the Mamurrng have emerged from a history of contact between Aboriginal people of western Arnhem Land and outsiders including Macassans, Balanda (Europeans or nonAboriginal people), Malay, and Japanese (see Berndt 1951:39; Macknight 1976), as well as a tradition of clan exogamy and intermarriage between various language groups in Arnhem Land (Berndt 1951: 162; Hiatt 1986: 11). This has in part brought together the various Mawng, Kunwinjku, Kunbarlang, Iwaidja, and Yolngu families living at Warruwi, where the ceremony took place. Mamurrng ceremonies are a feature of 'gift economies' traditional to Aboriginal Australia and other indigenous societies, where giving places the receiver under an obligation to receive and to make some kind of (unspecified) return in the future (Peterson, cited in Keen 2004: 337). Each clan may have a number of relationships of reciprocity to other neighbouring clans in different directions, creating an interdependent network of exchange within any given region of Aboriginal society.

In this article, I describe the unique set of circumstances that led to me becoming the recipient and focus of a Mamurng ceremony performed by singers and dancers from the community of Warruwi on South Goulburn Island in 2012, and draw connections between the Mamurrng I received and similar diplomacy ceremonies held for Balanda in the recent past. I suggest that Mamurrng ceremonies continue to play an important role in contemporary society in western Arnhem Land, as many Balanda now permanently live and work in communities such as Warruwi, and a variety of intercultural interactions take place on a daily basis between different Aboriginal language groups and between Aboriginal people and nonAboriginal researchers, journalists, government representatives, tourists, and others.

9 Myers (2002: 107) argues that Aboriginal land ownership consists primarily of 'control over the stories, objects, and rituals associated with the mythological ancestors of The Dreaming at a particular place', and that ceremonial exchange plays an essential role in this recognition and acceptance of shared identity, by turning cooperative ties among 'frequent co-residents' of a place into enduring ties between 'countrymen'. 
The Mamurrng ceremony was performed over two nights in three main sections: the 'warm-up' performed by the hosts on the first night for the recipients prior to the main event; the 'handover' of the mamurrng; and the 'thanks' performed by the recipients and others. My analysis focuses on these last two stages. By drawing attention to the relationship between changes in rhythmic mode and changes in the dance and development of the ceremony, I demonstrate how ceremony leaders gave careful consideration to their use of rhythmic mode, anticipating the emotion of the participants and presenting their songs using fast or slow modes, depending on where the ceremony is placed at any given point in time.

\section{Background to the Warruwi Mamurrng}

In 1952, photographer Axel Poignant travelled to Nagalarramba on the mouth of the Liverpool River in the north coast of Arnhem Land, accompanied by two Mawng-speaking men, Lazarus Lamilami and George Winunguj, as well as a Ndjébbana-speaking man from the Nagalarramba area. These men acted as guides, translators, and negotiators for Poignant while he remained at Nagalarramba for six weeks, equipped with his journal, camera, rolls of film, food rations, and tobacco. Various groups of Aboriginal people, including Burarra from the Blyth River estuary further east, visited during his stay, allowing him to document and participate in their daily lives. Towards the end of Poignant's stay, the Burarra group performed a ceremony they called a Rom (a different regional name for the same Mamurrng ceremony), in which the group sang, danced, and presented a painted and decorated pole (the rom) to Poignant as a gift for his having come to photograph them. In return, the Goulburn Island men that accompanied Poignant performed their songs for the Burarra group. Figure 5 shows George Winunguj, the ceremony leader for Inyjalarrku (mermaid) song-set, performing a yumparrparr (M: giant) dance as part of the Rom ceremony for Axel Poignant in 1952 (I will return to the significance of the dance that Winunguj is pictured performing later in this chapter). 


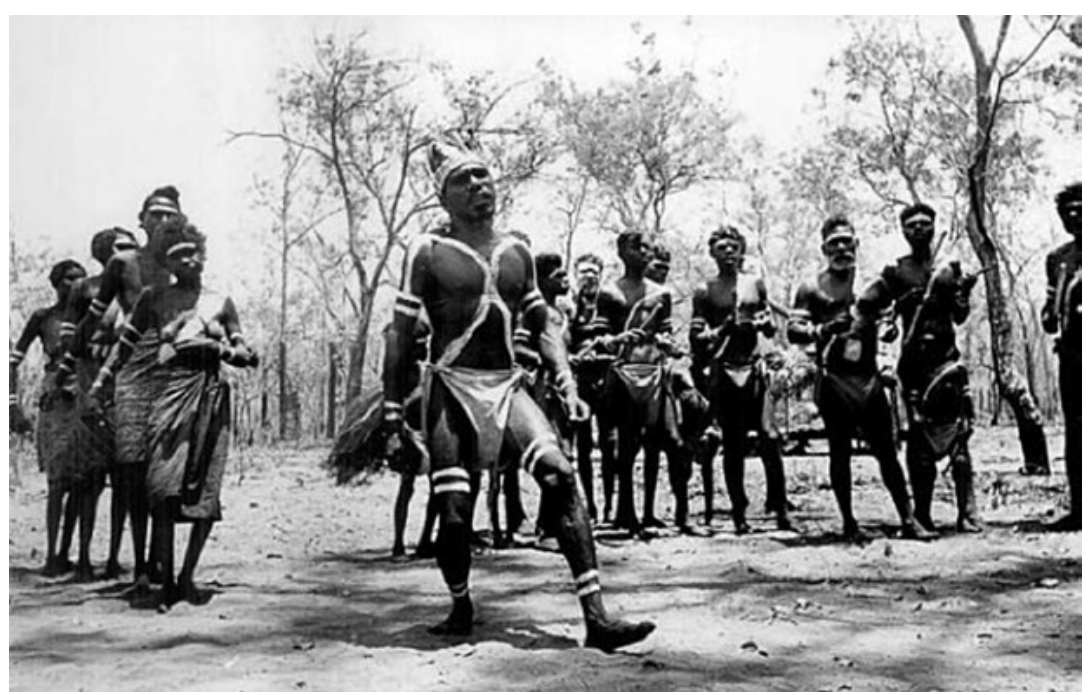

Figure 5. George Winunguj performs a Rom ceremony for Axel Poignant in 1952

Source: Axel Poignant (Poignant and Poignant 1996: 141), used with permission

As Roslyn Poignant has written, Axel Poignant's visit served to 'formalise the cross-cultural interaction taking place' and provided 'continuities both with a ceremonial way of relating to strangers in the past, and with later Rom ceremonies performed as rituals of diplomacy in Canberra' (Poignant and Poignant 1996: 4). This included a ceremony performed by Anbarra people of north-central Arnhem Land for the Australian Institute of Aboriginal Studies ${ }^{10}$ in Canberra in 1982, which preceded another Rom performance by the same group of people from Maningrida for the Minister of Aboriginal Affairs in 1995 (see Wild 1986b). Musicologist Stephen Wild, who was central to organising the Rom for AIATSIS in Canberra, explains how the Anbarra people were motivated to present the ceremony for a number of reasons:

10 Now, Australian Institute for Aboriginal and Torres Strait Islander Studies (AIATSIS). 
partly in recognition of the [role of AIATSIS] in documenting and preserving records of Anbarra culture, and in publishing several articles, books and records ... It was a gesture of goodwill also to the people of Canberra [who were invited to the event], and since Arnhem Land Aborigines are well aware of the national role of Canberra it was a gesture to Australia as a whole ... The ceremony was performed at the time of the annual meeting of the Institute's advisory committees and a meeting of the Council so that many researchers associated with the Institute could witness the proceedings. (Wild 1986a: xi-xii)

These recent ceremonies of exchange involving Balanda have all had a common purpose: to express goodwill on behalf of Aboriginal people of Arnhem Land toward the individuals (such as Axel Poignant and Stephen Wild) and institutions (such as AIATSIS) that interact with and represent them. Specifically, these ceremonies recognise Balanda who are in part responsible for interpreting, producing, and keeping records of Aboriginal culture produced by ceremony holders, and the importance of maintaining good relations between these groups into the future. ${ }^{11}$

Sixty years after George Winunguj led a performance of the Rom for Axel Poignant at Nagalarramba, the Warruwi Mamurrng was led by his son David Manmurulu in order to formalise another kind of intercultural interaction, this time between songmen and women of Goulburn and Croker Islands, Kunwinjku-speaking people from the community of Gunbalanya on the mainland, and a small group of Balanda researchers (see Figure 6). Manmurulu and his brothers inherited their Inyjalarrku songs from their father, George Winunguj. Many of the songs from Manmurulu's song-set are also songs that he has received in dreams from his father. Similarly, the Yanajanak song-set performed at the Warruwi Mamurrng led by Charlie Mangulda from Croker Island is made up of both songs Mangulda inherited from his grandfather as well as dreamconceived songs. Yanajanak is unique in that it is a song-set from the 'stone country' (the Murgenella region inland from the Coburg Peninsula) associated with Amurdak, a language belonging to the 'saltwater' Iwaidjan family (see Figure 1).

11 See, for example, the message from Anbarra ceremony holders to then principle of AIAS, Peter Ucko, in proposing the Canberra Rom, summarised in Meehan and Jones (1986: 25-26). 


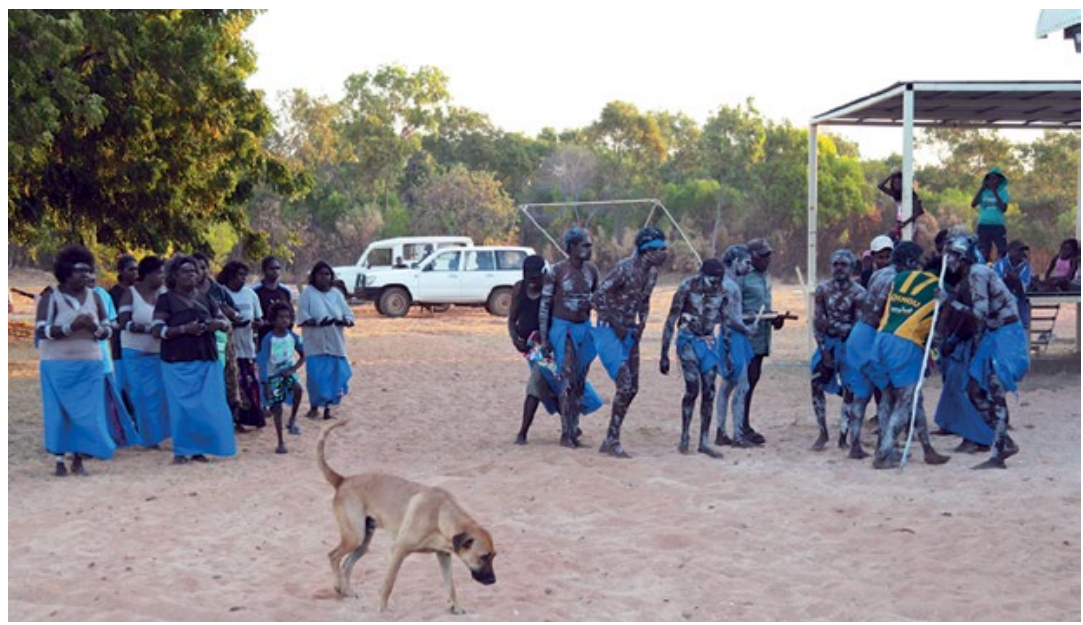

Figure 6. Charlie Mangulda and Harrison Cooper (holding clapsticks) sing Yanajanak at the Mamurrng ceremony at Warruwi for the author in 2012. Jenny Manmurulu (far left) leads the women's dancing, while David Manmurulu (centre, background) conceals the mamurrng pole from the recipient with cloth

Source: Martin Thomas, used with permission

The Warruwi Mamurrng had been initiated a year earlier in 2011 during the Annual Symposium for Indigenous Music and Dance in Darwin, which I attended. ${ }^{12}$ The circumstances of its inception bear some similarities to earlier Rom ceremonies mentioned above, in that it was initiated as a way of strengthening relations between Indigenous and nonIndigenous people from various communities and institutions, in this case with shared research interests around Aboriginal song and language. It was also a Bininj/Arrarrkpi (K/M: Aboriginal) response to a situation that arose during the symposium that had caused upset among some other Aboriginal groups in attendance. ${ }^{13}$ The following day, Croker Island songmen Charlie Mangulda and Archie Brown suggested to Allan Marett that a Mamurrng be held in order to reconcile for the upset caused, and to

12 The symposium was attended by Indigenous people from around Australia who continue to practise their song traditions, and convened by a group of researchers who have worked with these groups over a number of years, including musicologists Allan Marett and Linda Barwick.

13 A presentation about Bininj repatriating ancestral bones from their country caused anxiety for some people from outside of western Arnhem Land who were not prepared for the content and discussion of the bones. Western Arnhem Land participants held a smoking ceremony that evening in order to cleanse the area and the attendees of any spirits that might have lingered. 
formally acknowledge the relationship between researchers and ceremony holders. ${ }^{14}$ Marett later discussed the idea with David Manmurulu and Charlie Mangulda, who offered to host the ceremony.

To initiate a Mamurrng ceremony, a lock of hair from the youngest person in the family of the receiving group may be given to the giving group, who, in accepting the lock of hair, accepts the invitation to hold a Mamurrng. ${ }^{15}$ In this instance, I was the youngest member of the receiving group of researchers. Ordinarily, the recipient might be a small child from a different language group belonging to a distant clan, although, as with Axel Poignant's Rom, the recipients can also be adults. Nevertheless, I sensed my 'childlike' status, both in the 'Balanda world' of academia where I was just starting out with my $\mathrm{PhD}$ studies, and also in the 'Bininj/Arrarrkpi world', where I was just beginning to learn about manyardi and other aspects of Aboriginal cultural life. Aware of my role in the ceremonial context, I played my part as the somewhat naïve child-keeping myself deliberately uninformed about the ceremony so as to maximise the surprise once the performance took place. ${ }^{16}$ At the end of the symposium, Marett formally presented a lock of my hair to Manmurulu and Mangulda, and it was agreed that the ceremony would take place the following year on Croker or Goulburn Island. ${ }^{17}$

14 The Mamurrng was at the forefront of participants' minds, since Barwick, Birch, Mangulda, and Manmurulu had also given a presentation about a recent Mamurng ceremony performed at Croker Island.

15 Whilst the Mamurrng ceremony is different to the circumcision ceremonies of eastern and central Arnhem Land, it similarly signals some kind of transition or milestone in the social life of the recipient. Lazarus Lamilami describes other symbolic objects being sent to the giving group to initiate Mamurrng ceremonies such as a feather or tortoise shell representing a child's first hunt (Lamilami 1974: 181).

16 Many western Arnhem Land Bininj/Arrarrkpi that I spoke to emphasised the element of secrecy around the mamurrng, which serves to heighten the sense of anticipation once it is gradually revealed in performance. Songmen Russell Agalara and Solomon Nangamu explained to me that 'they're going to give you some gift ... it's a secret, for you' (Solomon Nangamu and Russell Agalara, interview, 25 August 2011).

17 For practical reasons, the Warruwi Mamurrng was held in the country of the givers, rather than the receivers, of the mamurrng (as is common practice). Whereas the initial idea was to include all the attendees of the symposium in the ceremony, limitations of logistics and budget necessitated that the visiting party be scaled down. In attendance were members of the Australian Research Council project 'Intercultural Inquiry in a Trans-national context: Exploring the Legacy of the 1948 AmericanAustralian Scientific Expedition to Arnhem Land', which funded my PhD fieldwork and supported the ceremony by funding the transport and accommodation for the visiting group, as well as buying materials and catering for the ceremony, and providing payments to performers. Also in attendance were linguist Bruce Birch, who was present at the inception of the Mamurng in 2011 in Darwin and has worked with Charlie Mangulda and Archie Brown on Iwaidja language, and linguist/musicologist Isabel O'Keeffe, who has worked with Mawng and Kun-barlang families at Warruwi. 
The Mamurrng performance is usually oriented around the recipient, who sits at the centre to receive the mamurrng, surrounded by family members who form part of the receiving group. Other members of the community usually gather to watch and encourage the performers (see Figure 7). For my Mamurrng, the receiving group included my partner, who, along with other members of the visiting group, helped to prepare food for the ceremony. My PhD supervisor, Linda Barwick, and her husband, Allan Marett, sat alongside me to receive the mamurrng and stood in as my 'Balanda parents'. Also part of the receiving group were members of the Bininj family into which I was adopted at Gunbalanya early on in my fieldwork, including two of my yabok, Donna and Rhonda Nadjamerrek, and Donna's daughters. Their parents were unable to attend; ${ }^{18}$ however, sitting alongside us in the place of our 'Bininj parents' were a Djalama clan man, whom we call 'father', and his wife Rosemary Urabadi from Goulburn Island, whom we call 'mother' (see Figure 7). Another important figure in the ceremony was songman and research collaborator Solomon Nangamu, who accompanied the 'Bininj family' and me from Gunbalanya, and joined his Mawng countrymen to perform the gift of the mamurrng.

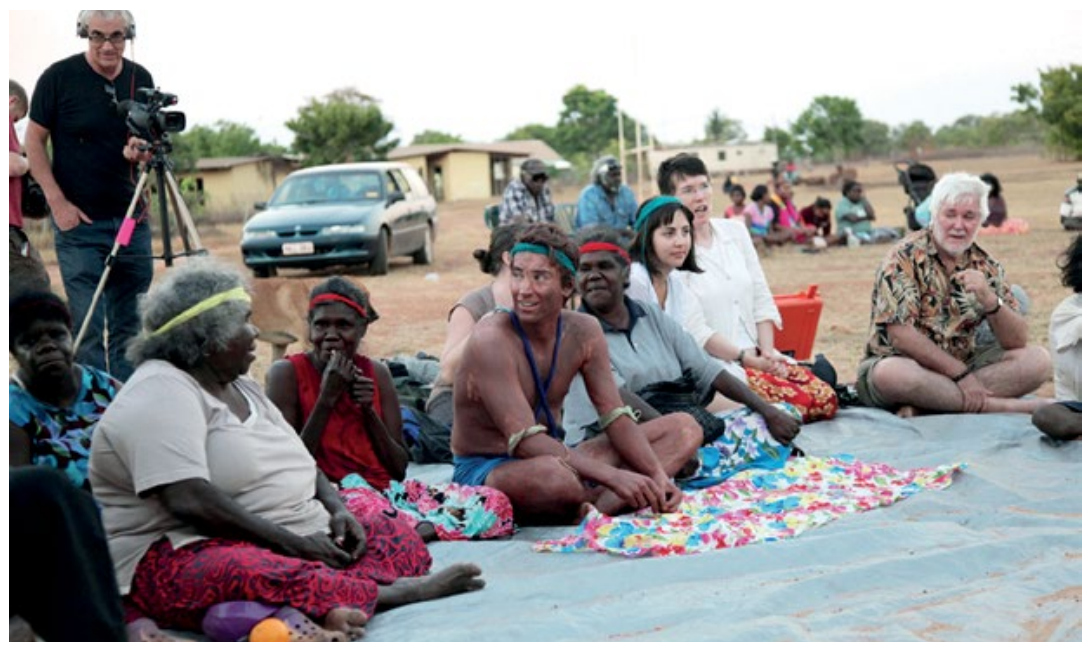

Figure 7. Rosemary Urabadi (karrang or mother of the recipient), Rhonda Nadjamerrek (yabok or sister of the recipient), Amanda Harris (obscured), Reuben Brown, Donna Nadjamerrek (yabok), Rachel Orzech, Linda Barwick, and Allan Marett. Background: Bruce Birch (standing), Archie Brown and Johnny Namayiwa (seated)

Source: Martin Thomas, used with permission

18 Donna's father, Wamud Namok, had passed away, and her mother was unable to make the long trip from her outstation at Kabulwanamayo. 


\section{Components of western Arnhem Land song}

A performance of manyardi consists of a number of song items, ${ }^{19}$ interspersed with social interaction between the audience, dance group, and singers. The boundaries that delineate the ceremonial action from the audience-related action are porous, so that events 'outside' of the performance may occasionally intrude upon the ceremonial action 'inside' the dance ground. Participation in the dancing and singing is similarly fluid: for the Warruwi Mamurrng (as with other ceremonial occasions), some performers stepped into the ceremony ground at particular moments to accompany with the didjeridu or to dance to songs that they were familiar with. ${ }^{20}$

Manyardi songs are typically short (between one and two minutes in duration), and strophic in form, featuring a verse that is repeated two or three times (see Barwick, Birch, and Evans 2007: 13). ${ }^{21}$ Each verse may consist of one or more melodic phrases of the song text (Text Phrase A, $\mathrm{B}, \mathrm{C}$, etc.), as well as vocables (sung vowels such as $o, a$, $i$, etc.). Some songs, such as those belonging to the Inyjalarrku song-set, also feature a vocal Introduction, which includes a short Text Phrase and vocables, sung before the main verse. Repetitions of the verse are generally separated by metrical units of clapstick beating with no singing (represented in the 'Clapstick beats/Metre' row of Figure 8), ${ }^{22}$ as well as longer 'Instrumental Sections' (IS) in which the singers sing vocables on the 'tonic' pitch of the arrawirr (see Marett, Barwick, and Ford 2013: 45). These sections typically feature more elaborate dancing, as the rhythmic mode changes (often the clapstick beating switches from even to an uneven pattern) and the dancers pause their movement as the nganangka skip the beat.

19 See definition of song in note 21.

20 Ceremony leader David Manmurulu also moved in and out of the space, directing and stagemanaging the action.

21 A song is considered to be a particular combination of text, rhythm, and melody that is relatively stable across numerous instances (or song items) in which it is performed. Songs may be realised slightly differently across song items, depending on the number of repetitions of the verse that the singer chooses to perform: e.g. in song item 2 of Figure 8, we see that the singers chose to perform song IL02 with one repetition of the verse, whereas in other instances/song items, they may choose two repetitions of the verse.

22 Note that the 'metre' in Figure 8 is my own interpretation of the subdivision of the clapstick beat; it is therefore indicative, rather than prescriptive. 


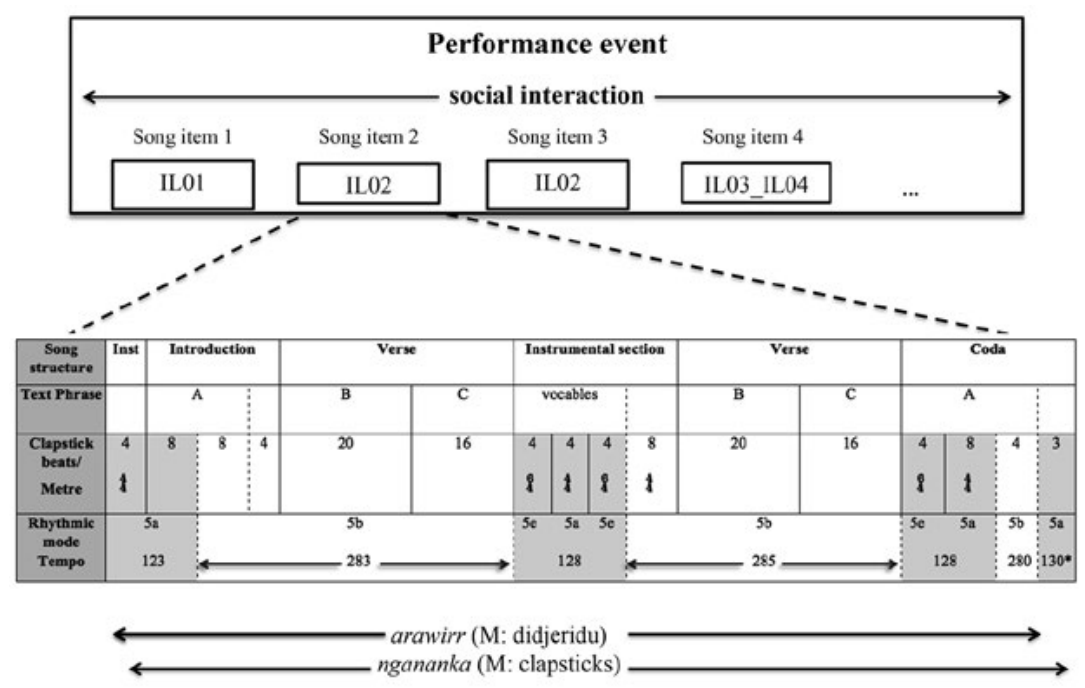

Figure 8. Structural components of western Arnhem Land performance, illustrated with the example of Inyjalarrku song IL02 (asterisk denotes approximate tempo reading based on small data sample)

Source: Adapted from Barwick, Birch, and Evans (2007)

Manyardi songs usually conclude with the vocal part and didjeridu accompaniment finishing first, leaving the clapsticks to beat a final 'terminating pattern' that signals the end of the song. ${ }^{23}$ Figure 8 illustrates these structural components of a performance of manyardi (as adapted from Barwick, Birch, and Evans's analysis of western Arnhem Land songs). The third expanded tier in the diagram shows an example of Inyjalarrku song IL02 performed as part of the Warruwi Mamurrng. ${ }^{24}$ (Note how changes in the rhythmic mode occur at the end of the verse and in the Introduction, Instrumental Section, and Coda.) The rhythmic modes featured in IL02 and other songs performed during the Mamurrng ceremony are summarised in Figure 9, which shows the rhythmic mode label, the tempo of the rhythmic mode, and the clapstick beating pattern.

23 See the final clapstick beat division in Figure 8. See also Barwick's observations of lirrga (2002: 73).

24 I follow song-naming conventions used by contributors to the Western Arnhem Land Song Database (Barwick et al. 2015), whereby two characters identify the repertory of a song-set (i.e. 'IL' for Inyjalarrku), and a two-digit number indicates a unique song ID belonging to the song-set. 
The summary in Figure 9 is adapted from the descriptive system devised by Marett, Barwick, and Ford (2013: 48) originally applied to wangga repertories, with my own additions for rhythmic modes distinctive to western Arnhem Land songs (i.e. 2c, 2d, 3c). Tempo ranges or bands are also loosely based on Marett's (2005: 204-5) and Marett, Barwick, and Ford's (2013: 58-59) analysis of tempo ranges for wangga repertories, where 'slow' = approx. 50-80 beats per minute (bpm); 'slow moderate' = approx. 81-95 bpm; 'moderate' = approx. $96-120 \mathrm{bpm}$; and 'fast $/$ fast doubled' $=$ approx. $121-300+\mathrm{bpm}$. A tempo band in one repertory may be very close to or may overlap a tempo band in another repertory (e.g. Inyjalarrku performed a moderate rhythmic mode of around 95-98 bpm, which was close to the slow moderate rhythmic mode performed by Yanajanak of 82-93 bpm).

\begin{tabular}{|c|c|c|}
\hline Rhythmic mode & Tempo & Clapsticks \\
\hline Rhythmic mode 1 & None (unmeasured) & None \\
\hline Rhythmic mode 2a & Slow & Even \\
\hline Rhythmic mode 2b & Slow & Uneven $[d: d t]$ \\
\hline $\begin{array}{l}\text { Rhythmic mode 2c } \\
\text { (Inyjalarrku Instrumental } \\
\text { Section mode) }\end{array}$ & Slow & 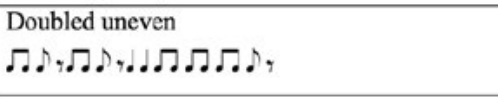 \\
\hline $\begin{array}{l}\text { Rhythmic mode 2d } \\
\text { (Inyjalarrku slow } \\
\text { 'turnaround' mode) }\end{array}$ & Slow & $\begin{array}{l}\text { Even } J . J . J d . \\
\text { (underlined beats performed with faster tempo) }\end{array}$ \\
\hline $\begin{array}{l}\text { Rhythmic mode } 3 \mathrm{c} \\
\text { (Yanajanak clapstick } \\
\text { terminating pattern) }\end{array}$ & Slow moderate & $\begin{array}{l}\text { Doubled suspended } \\
\text { F.F.F... }\end{array}$ \\
\hline Rhythmic mode 4a & Moderate & Even \\
\hline Rhythmic mode $5 \mathrm{a}$ & Fast & Even \\
\hline Rhythmic mode $5 \mathrm{~b}$ & Fast & Doubled \\
\hline Rhythmic mode $5 b[v a r]$ & Fast & Doubled suspended $(\mathbf{( \Omega )})$ \\
\hline Rhythmic mode 5c & Fast & Uneven (quadruple) $[\mathrm{J} / \mathrm{d}\}$ ] \\
\hline Rhythmic mode $5 \mathrm{c}$ & Fast & 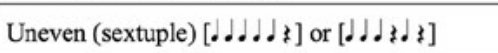 \\
\hline
\end{tabular}

Figure 9. Summary of rhythmic modes performed at the handover of the Warruwi Mamurrng

Source: Adapted from Marett, Barwick, and Ford (2013: 48)

\section{Handing over of the mamurrng}

The movement that accompanied the Mamurrng ceremony could be characterised as an elaborate and extended 'tease'. With the development of each new song, the dancers would advance toward the recipients, moving in a tight cluster. Eventually a dancer would break out and reveal 
the mamurrng to the recipient group, offering a closer look at the prize, before retreating to the cluster, concealing it again, and handing it to someone else (see Ceremonial Action column, Figure 10).

\begin{tabular}{|c|c|c|c|}
\hline $\begin{array}{l}\text { Song } \\
\text { item/s }\end{array}$ & Rhythmic Mode & Tempi & Ceremonial Action \\
\hline YJ01 & 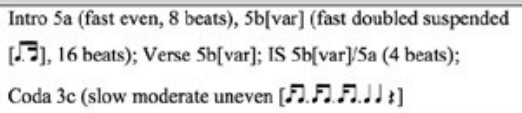 & $143 / 93$ & $\begin{array}{l}\text { Female dancers perform adjacent to the } \\
\text { ceremony ground }\end{array}$ \\
\hline YJ01 & Intro $5 \mathrm{a} / 5 \mathrm{~b}[\mathrm{var}][\mathbf{\sigma} \cdot \overline{\mathrm{J}}]) ;$ Verse $5 \mathrm{~b}[\mathrm{var}]$; IS $5 \mathrm{a} / 5 \mathrm{~b}[\mathrm{var}] ;$ Coda $3 \mathrm{c}$ & $145 / 85$ & $\begin{array}{l}\text { Females and males perform at back of } \\
\text { ceremony ground }\end{array}$ \\
\hline YJ02 & Intro $5 \mathrm{a} / 5 \mathrm{~b}[\mathrm{var}][\sqrt{.} \mathrm{J}]) ;$ Verse $5 \mathrm{~b}$ [var]; IS $5 \mathrm{a} / 5 \mathrm{~b}[$ var]; Coda $3 \mathrm{c}$ & $141 / 87$ & $\begin{array}{l}\text { Females and males edge closer to } \\
\text { recipients }\end{array}$ \\
\hline YJ03 & 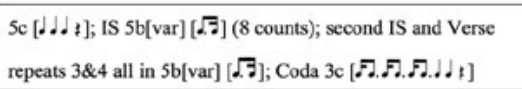 & $\begin{array}{l}129 / \\
146 / 89\end{array}$ & $\begin{array}{l}\text { Mamurrng appears; different male } \\
\text { dancers reveal it and 'present' it }\end{array}$ \\
\hline YJ03 & 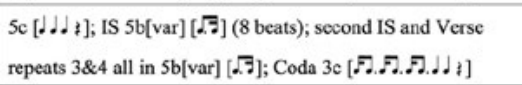 & $\begin{array}{l}129 / 148 \\
189\end{array}$ & $\begin{array}{l}\text { More male dancers present mamurng in } \\
\text { middle of ceremony ground }\end{array}$ \\
\hline YJ04 & 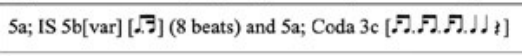 & $137 / 83$ & $\begin{array}{l}\text { Females split into two groups, flanking } \\
\text { males who move closer to recipients }\end{array}$ \\
\hline YJ04 & 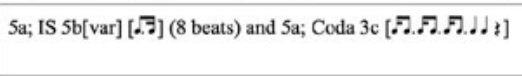 & $137 / 82$ & $\begin{array}{l}\text { Females and males now up close to } \\
\text { recipients; mamurrng laid at feet of } \\
\text { recipient at end of song (first handover) }\end{array}$ \\
\hline YJ05 & Intro $5 \mathrm{a} / 5 \mathrm{~b}[\mathrm{var}][\sqrt{.7}]) ;$ Verse $5 \mathrm{~b}[\mathrm{var}]$; IS $5 \mathrm{a} / 5 \mathrm{~b}[\mathrm{var}]$; Coda $3 \mathrm{c}$ & $146 / 91$ & $\begin{array}{l}\text { Practice during break/intermission for } \\
\text { dancers/audience }\end{array}$ \\
\hline YJ05 & Intro $5 \mathrm{a} / 5 \mathrm{~b}[\mathrm{var}][\sqrt{\mathrm{F}}])$; Verse $5 \mathrm{~b}[\mathrm{var}]$; IS $5 \mathrm{a} / 5 \mathrm{~b}[\mathrm{var}]$; Coda $3 \mathrm{c}$ & $148 / 92$ & \multirow[t]{2}{*}{$\begin{array}{l}\text { Males advance once more from middle of } \\
\text { ceremony ground }\end{array}$} \\
\hline YJ06 & Intro $5 \mathrm{a} / 5 \mathrm{~b}[\mathrm{var}][\sqrt{\mathrm{g}}])$; Verse $5 \mathrm{~b}[\mathrm{var}] ;$ IS $5 \mathrm{a} / 5 \mathrm{~b}[\mathrm{var}]$; Coda $3 \mathrm{c}$ & $149 / 90$ & \\
\hline YJ06 & Intro $5 \mathrm{a} / 5 \mathrm{~b}[\mathrm{var}][\Omega, \overline{.}])$; Verse $5 \mathrm{~b}[\mathrm{var}]$; IS $5 \mathrm{a} / 5 \mathrm{~b}[\mathrm{var}]$; Coda $3 \mathrm{c}$ & $148 / 90$ & $\begin{array}{l}\text { Males take the mamumng back as YJ } \\
\text { songs finish }\end{array}$ \\
\hline
\end{tabular}

Figure 10. Yanajanak songs performed as part of the handover of the mamurrng, showing the song item, rhythmic mode changes in relation to song structure, average tempi of rhythmic modes in beats per minute, and the corresponding ceremonial action

First the Yanajanak group, led by Charlie Mangulda and 'second singer'25 Harrison Cooper, performed a total of 11 song items, including six individual songs. Two main rhythmic modes underpinned the songs. YJ01, YJ02, YJ05, and YJ06 were predominantly in fast doubled suspended

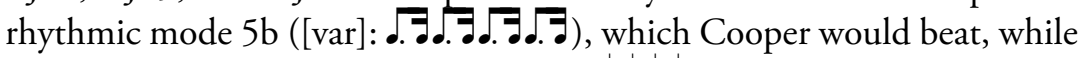
Mangulda beat a fast even rhythm $(5 \mathrm{a}: \mathrm{d} . d$ ) on the clapsticks. At the end of the song, the tempo slowed and Cooper beat an inverted version of his rhythm, before coming together with Mangulda for the final two beats ('Yanajanak clapstick terminating pattern'/rhythmic mode 3c: F. F. F. .. d). The Instrumental sections of these Yanajanak songs were characterised by a change of rhythm in the didjeridu pattern (roughly,

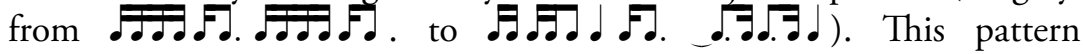

25 A term frequently used to describe young male relatives and 'apprentices' of the main songman who also sing and occasionally lead the songs in ceremony. 
mirrored the clapstick rhythm and cued a change in the clapsticks to fast even $(5 \mathrm{a}:\rfloor$.$d ), which in turn cued the male dancers' call. The second$ prominent rhythmic mode was fast uneven quadruple $(5 \mathrm{c}: \downarrow \downarrow d \downarrow)$. Song YJ03 began in this mode before returning to rhythmic mode $5 \mathrm{~b}$ ([var]: $\sqrt{.7}$ ) in the Instrumental Sections and in the third and fourth repeat of the verse (see Figure 10).

The Yanajanak group started their performance with a 'warm up' song (YJ01) accompanied by female dancers, positioned adjacent to the ceremony ground. They were far enough away so that we (the recipients) could just hear the action, but could not see it clearly. Then the singing group and male dancers took their position right up the back of the dance ground. For most ceremonies, the conventional arrangement is for kunborrk/manyardi singers to be seated at the front of the dance ground, facing the dancers. ${ }^{26}$ For the Mamurrng, however, the singing group (consisting of the lead singers, back-up singers, didjeridu player, and someone who stabilises the didjeridu) stood the entire time in a cluster, and traversed the ceremony ground toward me and the recipient group, as the dancers lead out in front and presented the mamurrng. At the beginning of each song, the male dancers huddled around the singers, facing inward. As the didjeridu began and the singers started to sing the first Text Phrase of the song, the dancers held their arms to the singers and gave an initiating call' to start the dance phrase. They called out 'argh!' twice, slapped their thighs or clapped their hands, and then gave a high-pitched elongated call 'yi::::::!'. Then they unfolded from the huddle and spread out in the direction of the audience, preparing for the Instrumental Section. In the Instrumental section (on beat 3) and in the Coda (on the final beat of the song), the dancers gave another short dance call, in which they clapped their hands or slapped their thighs, at the same time yelling 'kudda, yi::::!', as they turned their backs and retreated into a huddle.

In contrast to the externally driven style of the male dancers, the movement of the women was subtle and internally driven; with each clapstick beat they dipped their cupped hands from left to centre and right to centre, as if drawing the letter W in the air (see Figure 11). They formed a tight group and lined up on either side of the singers. As soon as the clapstick beat began, they started their arm movements, while stepping on the spot in time with the main clapstick beat. As the singers began

26 Apart from certain moments, such as during funeral ceremonies when they accompany mourners into the bow shelter and move to the grave for the interring of the body (see Brown 2014). 
the Instrumental Section, the women elevated their arm movements from chest to shoulder height, and back down again as the next Verse commenced. At the end of the song, as the clapstick beat slowed with the terminating pattern, the women's hand movements followed, until the final beat rang out (coinciding with the men's dance call described above), and they let their arms drop away, as though letting go of the rhythm they had been holding.

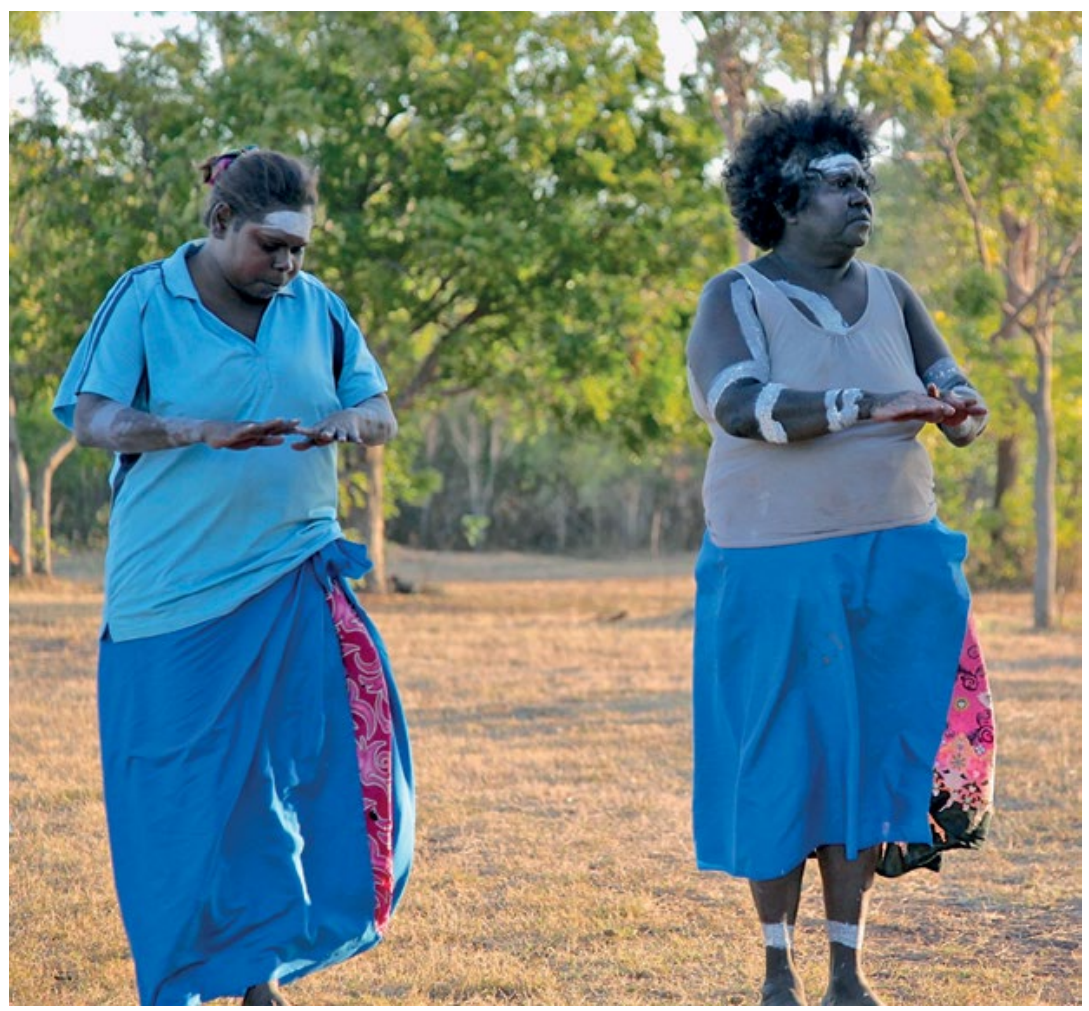

Figure 11. The women, led by Jenny Manmurulu (right), dance at the back of the ceremony ground to Yanajanak songs. They 'hold' the rhythm with their arm movements

Source: Martin Thomas, used with permission

A change of song and rhythmic mode frequently signalled a change of mood and a new development of the performance (see Figure 10). For example, when rhythmic mode $5 \mathrm{c}\left(\downarrow^{\circ} \downarrow\right)$ was introduced for the first time (song YJ03), the male dancers moved out from their tight huddle with their backs facing us, stepping three times, and pausing on the gapped beat, building a sense of anticipation. Eventually when they turned 
around, Rupert Manmurulu was holding the mamurrng in his hand-the first glimpse of it we had seen. Manmurulu led the male dancers closer to us, dancing with the mamurrng held outstretched in front of him, tilting it one way and another, following its direction with his body, as though it were leading him. He then returned to the group and they gave another 'initiating call' as the next dancer emerged with the mamurrng, coming forward and presenting it to the recipients (see Figure 12). Then, with the introduction of song YJ04 and a return to rhythmic mode $3 \mathrm{c}$ (F. F. F. . .), the women split into two groups, flanking the men as the ensemble advanced on the recipients and Roy Mangirryang presented the mamurng once more, this time placing it at our feet at the end of the song. Afterward, Rupert Manmurulu explained to me that the mamurrng was passed around to each dancer in relation to their traditional country, so that the dance roughly traced the journey of the mamurrng from the stone country (Gunbalanya, where my adopted family were from) to the saltwater country (Goulburn Island, Manmurulu's traditional country).

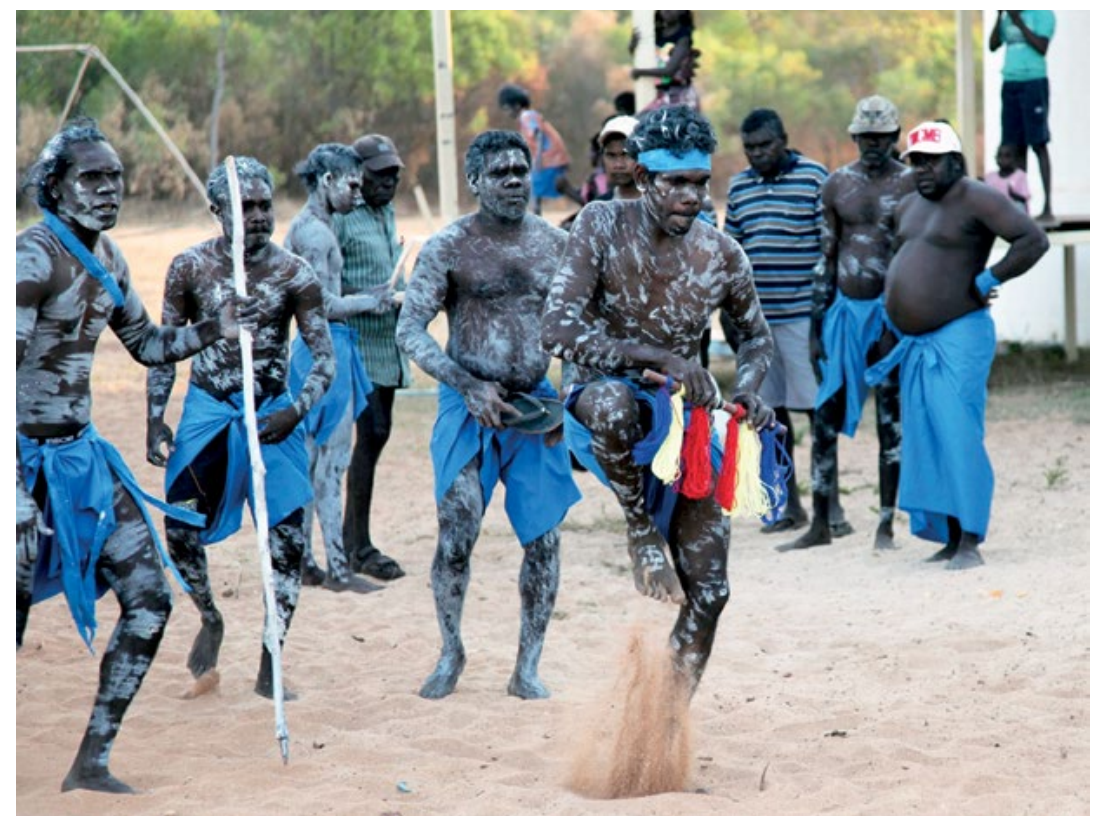

Figure 12. Roy Mangirryang advances with the mamurrng, holding it out toward the recipients as he stamps the ground during an Instrumental Section of YJ03. In the background, Harrison Cooper and Charlie Mangulda sing, supported by Solomon Nangamu, Maurice Gawayaku, and Rupert Manmurulu, who led the presentation

Source: Martin Thomas, used with permission 
After the first handover, with the sun fading, the dancers returned from a break with more urgency to their dancing, which was reflected in the tempo of the songs (see YJ05 and YJ06 in Figure 10). Once more the women flanked the men and with Charlie Mangulda leading them in song, the group converged on the recipients to take back the mamurrng (Figure 13).

With the mamurrng reclaimed, the Inyjalarrku group took over the singing, led by David Manmurulu and 'second singer' Rupert Manmurulu. They performed seven song items including four individual songs (two of which had been performed as a 'warm up' the night before). In keeping with other ceremonial performances, the overall tempo of the song items followed a slow-fast-slow trajectory, ${ }^{27}$ with a period of highenergy dancing in the middle section to accompany songs in fast doubled rhythmic mode (5b). During this period, the audience around us became very boisterous, encouraging the men to perform elaborate stamping phrases, yelling out 'action, action!' and showing their appreciation when Stanley Gameraidj, Brendan Marrgam, and other dancers responded by breaking away from the ensemble and dancing toward the audience. As with the Yanajanak performance, the dancers started far away and edged closer to the recipients with each song, until handing over the mamurrng (see 'Action' column, Figure 14). When it was the turn of the women to hand over the mamurng, their movements intensified, and they began swinging their arms more freely from side to side to the beat of the clapsticks (Figure 15). Rupert Manmurulu kept one eye on the singing ensemble and another on the female dancers, as they each took the mamurrng and came forward to present it, while Jenny Manmurulu, leading the female dancers, instructed him to keep singing, calling out 'one more!' This resulted in a very long version of the nigi (M: mother) song (IL50) involving six repeats of the verse. The women placed the mamurng down a second time at my feet and quickly took it back again, returning to the back of the ceremony ground once more.

27 Patterns of overall tempo in performances of western Arnhem Land song and their meaning are discussed further in Brown (2016). 


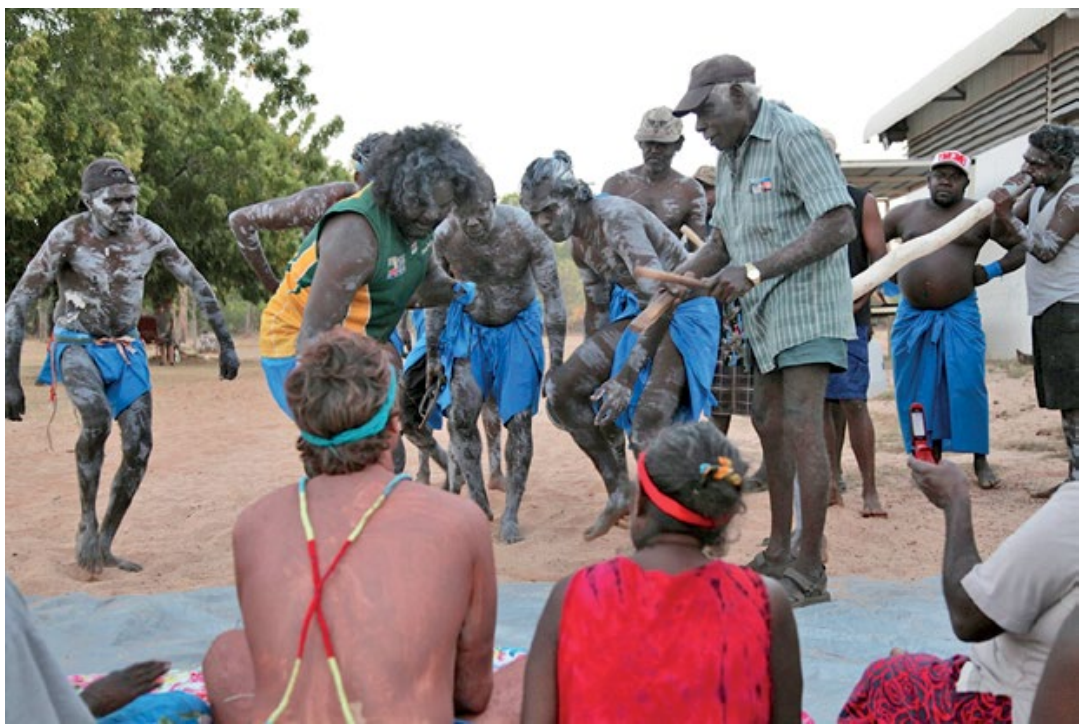

Figure 13. Brendan Marrgam, led by Yanajanak songman Charlie Mangulda, reaches forward and takes back the mamurng from the recipients

Source: Martin Thomas, used with permission

\begin{tabular}{|c|c|c|c|}
\hline Song item/s & Rhythmic Mode & Tempi & Action \\
\hline $\begin{array}{l}\text { IL02/ } \\
\text { ILS0 Nigi } \\
\text { (No. 1) }\end{array}$ & 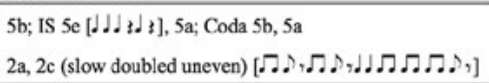 & $\begin{array}{l}289 / 130 \\
62 / 124\end{array}$ & $\begin{array}{l}\text { Inyjalarrku dancers start at back of } \\
\text { ceremony ground }\end{array}$ \\
\hline $\begin{array}{l}\text { IL } 02 / \\
\text { ILSO Nigi } \\
\text { (No. } 1-6 \mathrm{x} \\
\text { verse repeat) }\end{array}$ & 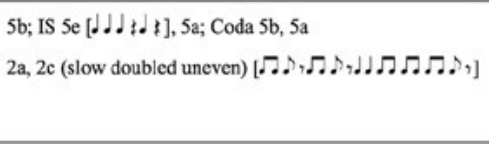 & $\begin{array}{l}286 / 129 \\
60 / 120\end{array}$ & $\begin{array}{l}\text { Dancers move to the centre of the } \\
\text { ceremony ground, daluk form a line in } \\
\text { front of recipients. One by onc, they } \\
\text { dance with the mamurmg, laying it } \\
\text { down (second handover) then taking it } \\
\text { away again }\end{array}$ \\
\hline IL02 & $5 \mathrm{~b} ;$ IS $5 \mathrm{e}[\mathrm{d} d \mathrm{l}, \mathrm{l}], 5 \mathrm{a}$; Coda $5 \mathrm{~b}, 5 \mathrm{a}$ & $290 / 136$ & \multirow{3}{*}{$\begin{array}{l}\text { Bininj and daluk start again from the } \\
\text { back of the ceremony ground. High- } \\
\text { energy dancing, jovial mood }\end{array}$} \\
\hline ILO2 & $5 \mathrm{~b}$; IS $5 \mathrm{e}[\mathrm{dJ} \mathrm{z} / \mathrm{l}], 5 \mathrm{a}$; Coda $5 \mathrm{~b}, 5 \mathrm{a}$ & $287 / 135$ & \\
\hline ILO2 & 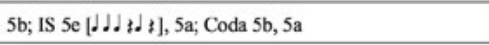 & $286 / 135$ & \\
\hline $\begin{array}{l}\text { IL06/ } \\
\text { IL07 Nigi } \\
\text { (No. 2) }\end{array}$ & 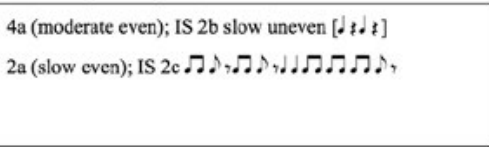 & $\begin{array}{l}98 / 71 \\
60 / 120\end{array}$ & $\begin{array}{l}\text { Yumparrparr (M: giant) emerges from } \\
\text { group, walks toward the recipients, } \\
\text { dancing in front of them. } \\
\text { Other dancers join the yumparrparr in } \\
\text { handing over the mamurmg one final } \\
\text { time (third handover). }\end{array}$ \\
\hline IL06 (Bobo) & 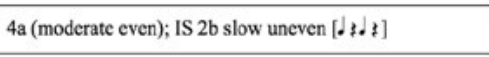 & $95 / 70$ & $\begin{array}{l}\text { Bininj and daluk all perform bobo for } \\
\text { the recipients }\end{array}$ \\
\hline
\end{tabular}

Figure 14. Inyjalarrku songs performed as part of the handover of the mamurrng 


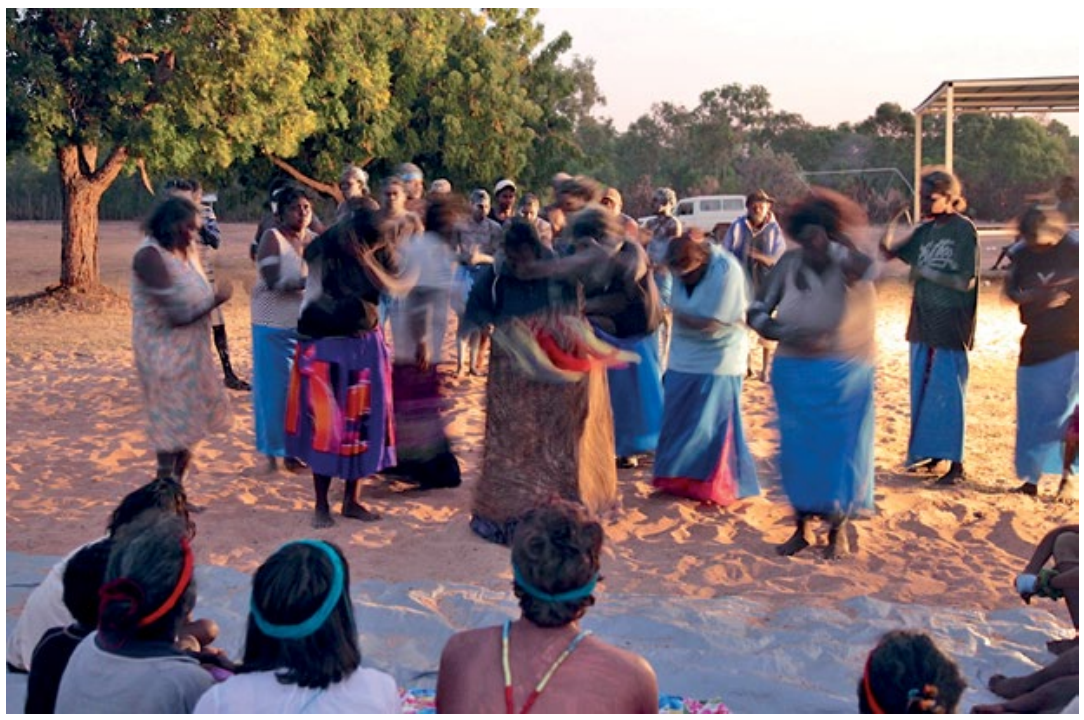

Figure 15. Later in the evening, the warramumpik (M: female) dancers for the Inyjalarrku song-set hand over the mamurrng, before taking it back once again

Source: Martin Thomas, used with permission

This elaborate 'tease' culminated with one final act of theatre, midway through song IL06. David Manmurulu, who had inconspicuously disappeared while the women were taking turns dancing with the mamurrng, re-emerged from the shadows at the back of the ceremony ground through the middle of the group of singers, covered from head to toe in delek, as the yumparrparr (M: giant). In Mawng mythology, the yumparparr are giant spirits that sometimes take the form of a shooting star. They are represented either with yellow and white ochre on each half of the body (split down the middle), or all white, as in Figure $4 .^{28}$ David Manmurulu learned the dance of the yumparrparr from his father George Winunguj (see Figure 5), and has since taught it to his sons Rupert and Renfred, who also perform it on special occasions. As the rhythmic mode shifted once more to slow even beating (2a) and the singers began singing the 'farewell' song (IL07 or Nigi (No. 2)), the yumparrparr took the mamurrng and danced with the women, ${ }^{29}$ who echoed his swaying

28 The yumparrparr is associated with the Nginji song-set, but is also performed as part of the Inyjalarrku song-set. See O'Keeffe (2016).

29 It is unusual for men to dance to slow rhythmic mode songs, which are usually reserved for women. The breaking of this performative convention arguably heightened the dramatic impact of the yumparparr dance. 
movements, swinging their arms outward from the hip, and raising one arm to their head on the third beat of rhythmic mode 2c. Meanwhile, the men surrounded the mamurrng and clapped along to the beat. The yumparrparr then placed the mamurrng at my feet one final time. Staying with the slow tempo, the women then formed a line in front of the recipients, with Manmurulu in the middle, and performed one final song (IL06) to say bobo and complete the handover.

With the formal part of the ceremony over, the final phase provided a counterbalance with a lighter, more reflective and relieving mood, as the recipients and other participants took part in exchanging various songs as 'thanks', and children as well as Balanda got involved in the dancing. The Inyjalarrku group performed two more songs (IL02) in fast doubled rhythmic mode 5b, during which Jenny Manmurulu invited the girls from Warruwi and from Gunbalanya to join in the dance. Mirrijpu (seagull) singers Solomon Nangamu and Russell Agalara then invited the recipients to sit with them as they sang two songs (MP06 and MP26) in slow and then in fast doubled rhythmic modes, with Rupert Manmurulu and Harrison Cooper accompanying on the didjeridu. Allan Marett then performed two wangga songs from two different repertories (Barrtjap and Walakandha wangga), which he had been given permission to perform in ceremony by songman Kenny Burrenjuck and Frank Dumoo (see Marett, Barwick, and Ford 2013: 13). Marett was assisted on the didjeridu by David Manmurulu, Nangamu, and Roderick Lee, while Linda Barwick led the dancing for the women (see Figure 16). This performance of a neighbouring Aboriginal genre led expertly by two Balanda stirred the interest of the audience, who also found it amusing watching local dancers dancing to the (less familiar) wangga songs. The male dancers entertained the audience with exaggerated movement and with their attempts to follow the rhythmic modes and pause at the right moment, sometimes misjudging the beat. Whilst they were able to

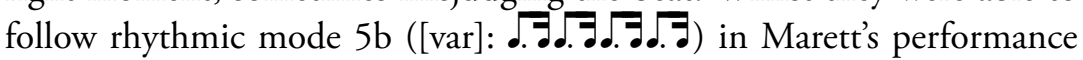
of Walakandha song 'Truwu', ${ }^{30}$ they had trouble clapping along to another rhythmic pattern that is less common among manyardi song-

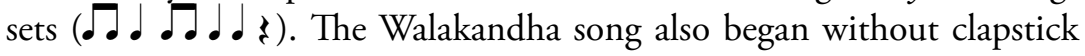
or didjeridu accompaniment (unaccompanied rhythmic mode 1), which is uncommon for western Arnhem Land manyardi, and created a sense

30 See Marett's recording (Mar88-39-s02 [AIATSIS A16829]) for another version of this song in Marri Tjevin language. For further analysis, see Marett, Barwick, and Ford (2013: 307-8). 
of suspense, which added to the audience's interest. Marett's second song 'Bangany-nyung Ngaya'31 was predominantly in fast uneven quadruple rhythmic mode $5 \mathrm{c}(. \downarrow$ ? $)$, similar to Yanajanak songs performed earlier in the evening. Marett repeated the song four times as various people volunteered to accompany him on the didjeridu, until they were able to accomplish the right rhythmic mode together in the Coda, and the song came out correctly.

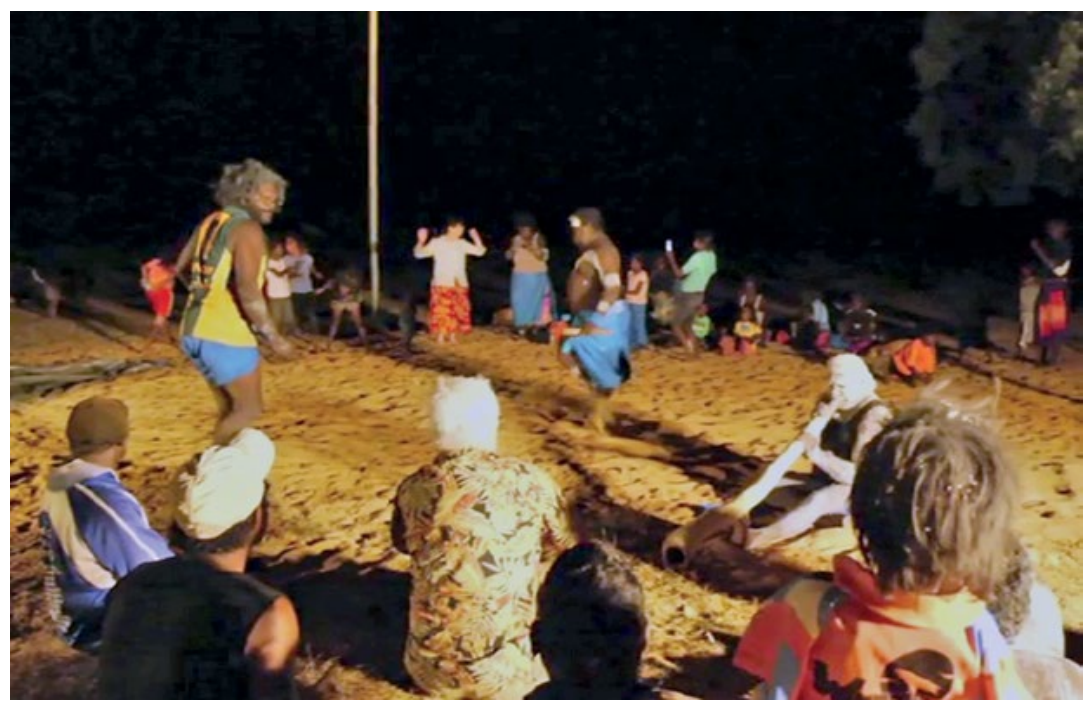

Figure 16. Allan Marett (centre) sings wangga with David Manmurulu accompanying on didjeridu and Linda Barwick leading the dancing for the younger warramumpik in the background with Jenny Manmurulu. Rupert Manmurulu and Brendan Marrgam dance in the middle of the ceremony ground

Source: Still from film by Gus Berger

\section{Conclusion}

By analysing the various clapstick beating patterns and changes in tempo in relation to two of the main stages of the Warruwi Mamurrng ceremony, this article has sought to show the way that rhythmic modes

31 This was the same song he had performed at the symposium in Darwin in 2011 when the Mamurrng was initiated. See Alice Moyle's recording (Moy68-05-s05 [AIATSIS A1144a]) for another version of this song, which is in Batjamalh language. For further analysis, see Marett, Barwick, and Ford (2013: 102-3). 
function as the 'pulse' of the ceremonial action in western Arnhem Land: underneath a dynamic soundtrack of sand flicking, dogs yelping, thighs slapping, babies crying, and onlookers calling out, it was the changes of song, clapstick beats, and singing of the Text Phrase that drove each stage of the Warruwi Mamurrng, and influenced minute aspects of the dance. Key ceremonial leaders-singers Charlie Mangulda and David Manmurulu, and dance leaders Jenny Manmurulu, Brendan Marrgam, and Stanley Gameraidj-made certain choices that steered the ceremony in a particular direction, while the dancers and the participants were allowed a degree of agency and spontaneity in the way that they followed this directive. As well as helping to reinforce the 'aural identity' of manyardi song-sets, rhythmic modes also function for Aboriginal people of the Top End as a kind of universal musical language that enables different language groups from different communities to exchange songs and dance to one another's repertories. Regardless of their familiarity with the song-set, both male and female dancers from Warruwi were able to participate in Marett's performance of wangga because they recognised and responded to the rhythmic modes.

Through the ethnographic account, I have attempted to give the reader a sense of the mamurrng's worth not in the material sense, but as an inalienable gift given in a ceremony of exchange. From my perspective as the recipient, the initial cutting of my hair seemed an unusual way of marking an important occasion. However, the significance became clear at the end of the ceremony, with the realisation that the lock of hair I gave away had been transformed into the mamurrng pole with beeswax, string, and wool, and danced through an elaborate performance, designed to overwhelm the senses and subvert expectations. Having the mamurrng returned to the recipient in this way helps someone understand that one is a small but essential part of a bigger network of people and cultures.

In multilingual communities such as Warruwi and Gunbalanya, where different language groups such as Kunwinjku and Mawng interact with one another, exchange ceremonies such as the Mamurrng continue to enact such cultural differences and to reinforce kinship networks that exist across families living in neighbouring communities. As Bininj/ Arrarrkpi interact ever more with non-Aboriginal co-workers, visitors, and researchers, the Mamurrng continues to find relevance as a way of formalising respectful relationships between locals and outsiders. 
The Warruwi Mamurrng was a uniquely Bininj/Arrarrkpi ceremonial response to a contemporary circumstance borne out of a conference involving both Indigenous and non-Indigenous collaborators. Through the process of staging the ceremony, relationships between researchers and their collaborators in the Warruwi and Gunbalanya communities were strengthened, and research aims were brought into line with Bininj/ Arrarrkpi protocols and ways of operating. By receiving the gift of the mamurrng, I personally felt that I was not only made welcome in Bininj/ Arrarrkpi society, but also given a place within that society (formalised through the dance in which my hair was passed from Bininj of the stone country to Arrarrkpi of the saltwater country). Observing Marett performing wangga songs that he had been entrusted to sing in ceremonial contexts and reflecting on the overjoyed response to his performance by people at Warruwi, I was also reminded how Balanda can participate in ceremonial exchange in culturally meaningful and appropriate ways: often it is through ceremony that we find our place among others and our sense of belonging.

\section{Notes on recordings}

In constructing my analysis of the performance for this article, I relied on audio and video recordings of the Warruwi Mamurrng produced by Gus Berger, Bruce Birch, and Isabel O'Keeffe. This included video file 20120810IBv01.mov and audio file 20120810IB01.wav compiled by O'Keeffe of the first evening's performance, as well as video files 20120811IOv01.mov edited by Isabel O'Keeffe and an edited DVD produced by Gus Berger of the final evening's performances. These recordings are housed in PARADISEC's archive. File excerpts and time codes relating to song items performed as part of the ceremony and discussed in this article are provided below.

'Hand Over'

\begin{tabular}{|l|l|}
\hline File name & Time code \\
\hline 20120811IOv01-01-YJ01 & 00:00:03.300 - 00:01:34.300 \\
\hline 201208111Ov01-02-YJ01 & 00:01:46.700 - 00:03:04.500 \\
\hline 201208111Ov01-03-YJ02 & $00: 03: 27.500-00: 04: 56.900$ \\
\hline 201208111 Ov01-04-YJ03 & $00: 05: 15.400-00: 07: 22.800$ \\
\hline
\end{tabular}




\begin{tabular}{|l|l|}
\hline File name & Time code \\
\hline 20120811IOv01-05-YJ03 & $00: 07: 45.500-00: 09: 56.100$ \\
\hline 20120811IOv01-06-YJ04 & $00: 10: 03.400-00: 12: 08.800$ \\
\hline 20120811 IOv01-07-YJ04 & $00: 12: 18.700-00: 14: 13.200$ \\
\hline 20120811 IOv01-08-YJ05 & $00: 14: 15.800-00: 14: 46.700$ \\
\hline 20120811 IOv01-09-YJ05 & $00: 14: 51.300-00: 16: 17.600$ \\
\hline 20120811 IOv01-10-YJ06 & $00: 16: 32.400-00: 18: 22.000$ \\
\hline 20120811 IOv01-11-YJ06 & $00: 19: 31.400-00: 21: 05.100$ \\
\hline 20120811 IOv01-12-IL02_IL50 & $00: 21: 31.400-00: 22: 50.500$ \\
\hline 20120811 IOv01-13-IL02_IL50 & $00: 22: 56.000-00: 25: 53.600$ \\
\hline 20120811 IOv01-14-IL02 & $00: 25: 54.100-00: 26: 49.300$ \\
\hline 20120811 IOv01-15-IL02 & $00: 26: 49.500-00: 28: 00.500$ \\
\hline 20120811 IOv01-16-IL02 & $00: 28: 01.000-00: 29: 06.600$ \\
\hline 20120811 IOv01-17-IL06_IL07 & $00: 29: 24.900-00: 32: 13.500$ \\
\hline 20120811 IOv01-18-IL06 & $00: 34: 05.600-00: 36: 41.200$ \\
\hline
\end{tabular}

\section{'Thanks'}

\begin{tabular}{|l|l|}
\hline File name & Time code \\
\hline 20120811IOv01-19-IL02 & $00: 37: 08.600-00: 38: 11.800$ \\
\hline 20120811IOv01-20-IL02 & $00: 38: 14.400-00: 39: 10.700$ \\
\hline GUS_VTS_01_1-01-MP06 & $00: 13: 41.500-00: 14: 30.900$ \\
\hline GUS_VTS_01_1-02-MP26 & $00: 14: 30.900-00: 14: 57.400$ \\
\hline GUS_VTS_01_1-03-MP26 & $00: 14: 57.800-00: 15: 35.400$ \\
\hline GUS_VTS_01_1-04-MP26 & $00: 15: 36.500-00: 16: 12.100$ \\
\hline GUS_VTS_01_1-05-Truwu & $00: 16: 25.200-00: 18: 30.600$ \\
\hline GUS_VTS_01_2-01-Truwu & $00: 00: 00.100-00: 02: 06.800$ \\
\hline GUS_VTS_01_2-02-Bangany & $00: 02: 07.400-00: 03: 21.600$ \\
\hline GUS_VTS_01_2-03-Bangany & $00: 03: 24.500-00: 04: 21.100$ \\
\hline GUS_VTS_01_2-04-Bangany & $00: 04: 21.550-00: 05: 19.950$ \\
\hline
\end{tabular}

\section{Acknowledgements}

Thank you to Bininj and Arrarrkpi collaborators for their contributions to this article, in particular Jenny Manmurulu, David Manmurulu, and Solomon Nangamu; and to Linda Barwick, Martin Thomas, and Paul Dwyer for their helpful comments on earlier drafts. 


\section{References cited}

Anderson, Gregory D. 1995. 'Striking a Balance: Limited Variability in Performances of a Clan Song Series from Arnhem Land.' In The Essence of Singing and the Substance of Song: Recent Responses to the Aboriginal Performing Arts and Other Essays in Honour of Catherine Ellis, edited by Linda Barwick, Allan Marett, and Guy Tunstill, 13-25. Sydney: University of Sydney Press.

Barwick, Linda. 2002. 'Tempo Bands, Metre and Rhythmic Mode in Marri Ngarr "Church Lirrga" Songs.' Australasian Music Research 7: 67-83.

—. 2011. 'Musical Form and Style in Murriny Patha Djanba Songs at Wadeye (Northern Territory, Australia).' In Analytical and CrossCultural Studies in World Music, edited by Michael Tenzer and John Roeder, 317-51. Oxford Scholarship Online: Oxford University Press.

Barwick, Linda, Bruce Birch, and Nicholas Evans. 2007. 'Iwaidja Jurtbirrk songs: Bringing Language and Music Together.' Australian Aboriginal Studies 2007 (2): 6-34. Canberra: Aboriginal Studies Press.

Barwick, Linda, Nicholas Evans, Murray Garde, Allan Marett, with assistance from Isabel O'Keeffe, Ruth Singer, and Bruce Birch. 2015. 'The West Arnhem Land Song Project Metadata Database, 20112015.' Funded by the Hans Rousing Endangered Languages Project. elar.soas.ac.uk/deposit/0155.

Barwick, Linda, Isabel O'Keeffe, and Ruth Singer. 2013. 'Dilemmas in Interpretation: Contemporary Perspectives on Berndt's Goulburn Island Song Documentation.' In Little Paintings, Big Stories: Gossip Songs of Western Arnhem Land, edited by John Stanton, 46-71. Nedlands, WA: University of Western Australia, Berndt Museum of Anthropology.

Berndt, Ronald M. 1951. 'Ceremonial Exchange in Western Arnhem Land.' Southwestern Journal of Anthropology 7 (2): 156-76. doi.org/ 10.1086/soutjanth.7.2.3628621.

Brown, Reuben. 2014. 'The Role of Songs in Connecting the Living and the Dead: A Funeral Ceremony for Nakodjok in Western Arnhem Land.' In Circulating Cultures: Exchanges of Australian Indigenous Music, Dance and Media, edited by Amanda Harris, 169-201. Canberra: ANU Press. 
—_. 2016. 'Following Footsteps: The Kun-borrk/Manyardi Song Tradition and its Role in Western Arnhem Land Society.' PhD diss., Sydney Conservatorium of Music, University of Sydney.

Corn, Aaron D. S. 2002. 'Burr-Gi Wargugu Ngu-Ninya Rrawa: Expressions of Ancestry and Country in Songs by the Letterstick Band.' Musicology Australia 25 (1): 76-101. doi.org/10.1080/08145857.2002.10415995.

Evans, Nicholas. 2010. Dying Words: Endangered Languages and What They Have to Tell Us. Chichester, UK: Wiley-Blackwell.

Garde, Murray. 2006. 'The Language of Kun-borrk in Western Arnhem Land.' Musicology Australia 28: 59-89.

Hiatt, L. R. 1986. 'Rom in Arnhem Land.' In Rom: An Aboriginal Ritual of Diplomacy, edited by Stephen A. Wild, 3-13. AIAS new series, 59. Canberra: Australian Institute of Aboriginal Studies.

Keen, Ian. 2004. Aboriginal Economy and Society: Australia at the Threshold of Colonisation. South Melbourne, Vic.: Oxford University Press.

Lamilami, Lazarus. 1974. Lamilami Speaks, the Cry Went Up: A Story of the People of Goulburn Islands, North Australia. Sydney: Ure Smith.

Macknight, C. C. 1976. The Voyage to Marege: Macassan Trepangers in Northern Australia. Carlton, Vic.: Melbourne University Press.

Marett, Allan. 2005. Songs, Dreamings, and Ghosts: The Wangga of North Australia. Middletown, CT: Wesleyan University Press.

Marett, Allan, Linda Barwick, and Lysbeth Ford. 2013. For the Sake of a Song: Wangga Songmen and Their Repertories, The Indigenous Music of Australia, Book 2. Sydney: University of Sydney Press.

Meehan, Betty, and Rhys Jones. 1986. 'From Anadjerramiya to Canberra.' In Rom: An Aboriginal Ritual of Diplomacy, edited by Stephen A. Wild, 15-31. AIAS new series, 59. Canberra: Australian Institute of Aboriginal Studies.

Myers, Fred. 2002. 'Ways of Place-Making.' La Ricerca Folklorica (45): 101-19. doi.org/10.2307/1480159. 
O'Keeffe, Isabel. 2007. 'Sung and Spoken: An Analysis of Two Different Versions of a Kun-barlang Love Song.' Australian Aboriginal Studies 2007 (2): 46-62.

—. 2010. 'Kaddikkaddik Ka-wokdjanganj "Kaddikkaddik Spoke": Language and Music of the Kun-barlang Kaddikkaddik Songs from Western Arnhem Land.' Australian Journal of Linguistics 30 (1): 35-51. doi.org/10.1080/07268600903134012.

—. 2016. 'Manifestations of Multilingualism in the Manyardil Kun-borrk Song Traditions of Western Arnhem Land.' PhD thesis, University of Melbourne.

Poignant, Roslyn, and Axel Poignant. 1996. Encounter at Nagalarramba. Canberra: National Library of Australia.

Rose, Deborah Bird. 1996. Nourishing Terrains: Australian Aboriginal Views of Landscape and Wilderness. Australian Heritage Commission, 7. Canberra: Australian Heritage Commission,.

Toner, Peter. 2001. 'Where the Echoes Have Gone: A Yolngu Musical Anthropology.' PhD diss., The Australian National University.

Treloyn, Sally. 2014. 'Cross and Square: Variegation in the Transmission of Songs and Musical Styles between the Kimberley and Daly Regions of Northern Australia.' In Circulating Cultures: Exchanges of Australian Indigenous Music, Dance and Media, edited by Amanda Harris, 203-38. Canberra: ANU Press.

Weiner, Annette. 1992. Inalienable Possessions: The Paradox of Keepingwhile-giving. Berkeley: University of California Press. doi.org/10.1525/ california/9780520076037.001.0001.

Wild, Stephen A. 1986a. 'Introduction.' In Rom: An Aboriginal Ritual of Diplomacy, edited by Stephen A. Wild, xi-xiii. AIAS new series, 59. Canberra: Australian Institute of Aboriginal Studies.

- 1986b. ed. Rom: An Aboriginal Ritual of Diplomacy. AIAS new series, 59. Canberra: Australian Institute of Aboriginal Studies. 
This text is taken from A Distinctive Voice in the Antipodes: Essays in Honour of Stephen A. Wild, edited by Kirsty Gillespie, Sally Treloyn and Don Niles, published 2017 by ANU Press, The Australian National University,

Canberra, Australia.

dx.doi.org/10.22459/DVA.07.2017.01 